(6) A special design permitted us to adapt individuals to more and more concentrated media, by gradually increasing the sea-water content in the aquarium in which the fish were put, in such a manner that the fresh water was replaced by sea-water, within 28 or $36 \mathrm{hr}$. When fresh-water replacement was accomplished within $28 \mathrm{hr}$., all fish without exception died during the $24 \mathrm{hr}$. following. When the replacement was accomplished within $36 \mathrm{hr}$., only three individuals (out of fifty fish) died. This means that the minimum time for adaptation to sea-water is about $36 \mathrm{hr}$.

(7) Several series of 25 individuals each were adapted to sea-water during at least 3 wk.; they were transferred to fresh water and then returned again to sea-water, $24,36,48$ or $72 \mathrm{hr}$. after. The results obtained were as follows:

$\begin{array}{cc}\text { Time (hr., in fresh water) } & \text { No. dead } \\ 24 & \text { none } \\ 36 & 4 \text { individuals } \\ 46 & 8 \text { individuals } \\ 72 & 20 \text { individuals }\end{array}$

This means that individuals begin to lose their adaptation to sea-water when kept in fresh water for about $36 \mathrm{hr}$, that is, the minimum time for adaptation to sea-water is approximately equivalent to that during which the fish keep their adaptation to sea-water.

(8) Having noticed during the previous experiments that males usually die before the females, 100 adult individuals of both sexes were transferred directly to pure sea-water. Five and a half hours after, fish began to die (especially males). Six and a half hours after they began to die, all males were already dead, but only 55 females were quite dead. The remaining females died within the following $12 \mathrm{hr}$.

We are aware of the probable existence of the factor, namely, weight of the individuals in the mortality, since the youngest adult female is usually heavier than the biggest male. However, we think that this factor is not exclusive. For the same sex (male), the histogram has shown that mortality was not a function of the weight, but represented by a Gaussian curve.

Laboratoire de Biologie Animale,

T. MoHsen

Laboratoire de Zoologie,

Faculté des Sciences, Dakar.

${ }^{1}$ Pickford, G., and Atz, W., N.Y. Zool. Soc. Pub., 156 (1955).

\section{Effect of Temperature on Apis indica Workers}

RECENT work on the effect of environmental temperature on the European honeybee, Apis mellifer $a^{1-3}$, has been partially repeated with two colonies of Apis indica brought from Ceylon by $\mathrm{Mr}$. L. A. S. Perera.

Groups of $100 \mathrm{~A}$. indica were kept in cages for three days with sugar syrup ( 2 parts sugar : 1 part water) and water at temperatures from $20^{\circ}$ to $40^{\circ} \mathrm{C}$., three groups being kept at each temperature; the amount of food and water consumed, the temperatures at the centres of the groups, and the number of bees which died, were recorded. The results are given in Table 1. Comparable results for A. mellifera are in brackets.

\begin{tabular}{|c|c|c|c|c|}
\hline $\begin{array}{c}\text { Environmental } \\
\text { temperature } \\
\left({ }^{\circ} \mathrm{C} .\right)\end{array}$ & $\begin{array}{l}\text { Mean tem- } \\
\text { perature of } \\
\text { groups }\left({ }^{\circ} \mathrm{C} .\right)\end{array}$ & $\begin{array}{l}\text { Mean con } \\
\text { (mm. }^{3} \text { ) per b } \\
\text { Sugar syrup }\end{array}$ & $\begin{array}{l}\text { ssumption } \\
\text { bee per day } \\
\text { Water }\end{array}$ & $\begin{array}{c}\text { Mean No. } \\
\text { dead at } \\
\text { end of day } 1\end{array}$ \\
\hline $\begin{array}{l}20 \\
25 \\
30 \\
35 \\
40\end{array}$ & $\begin{array}{l}24.0(24 \cdot 9) \\
29.3(29 \cdot 6) \\
31.4(30 \cdot 8) \\
35.7(35 \cdot 0) \\
39 \cdot 6(39 \cdot 2)\end{array}$ & $\begin{array}{r}17 \cdot 1(31 \cdot 7) \\
17 \cdot 2(21 \cdot 3) \\
14 \cdot 3(11 \cdot 5) \\
11.6(18 \cdot 6) \\
1.9(5 \cdot 5)\end{array}$ & $\begin{array}{cl}0.1 & (0) \\
0.1 & (0.3) \\
0.1 & (0.5) \\
1.2 & (10.1) \\
21.8 & (16.7)\end{array}$ & $\begin{array}{rr}8 \cdot 9 & (4 \cdot 0) \\
5 \cdot 5 & (1 \cdot 0) \\
4 \cdot 0 & (4 \cdot 0) \\
1.0 & (3 \cdot 7) \\
15 \cdot 0(13 \cdot 8)\end{array}$ \\
\hline
\end{tabular}

Groups of $A$. indica at $20^{\circ}$ and $25^{\circ}$ C. took similar amounts of food and were both about $4 \mathrm{deg}$. C. above environmental temperature but, in general, the lower the environmental temperature the greater the difference between it and the group temperature, and the greater the food consumption. Thus $A$. indica like $A$. mellifer $a$ responds to low temperature by increased food consumption, indicating increased metabolism, and increased production of heat. At $40^{\circ} \mathrm{C}$. both species took little food but large quantities of water, reflecting a high rate of losing water. The mortality of both species was similar at the higher temperatures, but was greater for $A$. indica at the lower temperatures.

To find the temperature at which the two species enter chill coma single $A$. indica and $A$. mellifera workers were taken from their hive entrances and placed at low temperatures. Table 2 shows the numbers that moved and were still after exposure for $\mathrm{I} \mathrm{hr}$. All those that were still, moved again when the temperature was raised.

\begin{tabular}{|c|c|c|c|c|}
\multicolumn{2}{c|}{ Table 2 } \\
\hline $\begin{array}{c}\text { Environmental } \\
\text { temperature ( }{ }^{\circ} \text { C.) }\end{array}$ & \multicolumn{2}{|c|}{$\begin{array}{c}\text { A. indica } \\
\text { Moved }\end{array}$} & $\begin{array}{c}\text { Still } \\
\text { A. mellifera } \\
\text { Still }\end{array}$ \\
\hline 8 & 0 & 12 & 0 & 12 \\
9 & 0 & 17 & 3 & 15 \\
10 & 1 & 30 & 20 & 10 \\
11 & 22 & 22 & 33 & 10 \\
12 & 15 & 12 & 21 & 3 \\
13 & 21 & 4 & 26 & 0 \\
14 & 6 & 0 & 6 & 0 \\
\hline
\end{tabular}

Unfortunately, the $A$. indica colonies died before much information could be obtained on the effect of previous acclimatization on ehill coma temperatures. However, after acclimatization at $35^{\circ} \mathrm{C}$. for $24 \mathrm{hr}$. only 6 out of $21 \mathrm{~A}$. indica moved at $11^{\circ}$ or $12^{\circ} \mathrm{C}$., whereas 12 out of $18 \mathrm{~A}$. mellifera moved. Thus the species differed in behaviour $(P<0.05)$ even when acclimatized to the same temperature. Both appeared to have a higher chill coma temperature after being kept at temperatures higher than they would have experienced at their hive entrances.

Mellanby ${ }^{4}$ found that Cimex lectularius (from temperate regions) was more resistant to starvation and desiccation, and could breed more successfully at low temperatures than C. rotundatus (from tropical regions) but found no circumstance in which $C$. rotundatus was markedly superior. Our results indicate that $A$. mellifera is more adapted to temperate climates than $A$. indica, but do not, show that $A$. indica has any corresponding adaptation to the tropics.

Rothamsted Experimental Station,

J. B. FreE

YVETTE SPENCER-BOOTH Harpenden, Herts. ${ }^{1}$ Free, J. B., and Spencer-Booth, Yvette, J. Exp. Biol., 35, 930

${ }^{2}$ Free, J. B., and Spencer-Booth, Yvette, Bee World, 40, 173 (1959). ${ }^{3}$ Free, J. B., and Spencer-Booth, Yvette, Ent. Exp. and App., 3, 222 (1960).

4 Mellanby, K., Parasitology, 37, 111 (1935). 